\title{
Corporate Social Responsibility Accounting and Financial Performance of Insurance Companies in Nigeria (2007-2016) ${ }^{1}$ EHIOGHIREN, Efe Efosa. PhD, ${ }^{2}$ ENEH, ONYINYE
}

\author{
${ }^{1}$ Department of Accounting, Shaka Polytechnic, Edo State, Nigeria \\ Correspondence: ehioghiren2004@ gmail.com \\ ${ }^{2}$ Department of Accountancy, Nnamid Azikiwe University, Awka
}

\begin{abstract}
Before now it is believe that it is only company that their activities adversely affect the environment that should be socially responsible. This has change over the years as some country has made it mandatory for business to be socially responsible without which they cannot do business. For insurance company, their activities have to do with rendering of services and as such do not destroy the environment. The main objective of the study was to determine corporate social responsibility accounting and financial performance of insurance companies in Nigeria. The research design adopted for the study is expo facto research design. The population of the study consists of all the 40 companies quoted in the Nigeria Stock Exchange as at December 2016. A sample of 25 insurance companies was selected base on their size from the population of the insurance companies. Data for the study were obtained from annual reports for the period of ten (10) years ranging from 2007 to 2016. Multiple regression analysis was carried out to determine the desire relationship. Findings show a significant relationship between corporate social responsibility accounting and return on capital employed and net profit margin, while a negative relationship with earnings per share. The implication of the findings is that there is evidence of conscious effort of the sampled insurance companies to discharge their social responsibility. The study recommends among other that management should be proactive and ensure that their social responsibility policies are adequately implemented, and ensure that Nigerian companies comply with government laws regarding business regulation in the country.
\end{abstract}

Keywords: Corporate Social Responsibility, Social Accounting, Insurance Companies, Financial performance.

\section{INTRODUCTION}

Business corporations have traditionally been conceptualized as economic entities with the main responsibility for producing goods and providing services as efficiently as possible. With the advent of the sustainable development these corporations began to move away from their narrow economic conception of responsibility and to make profound strategic adjustments in response to environmental pressures and changing societal expectations (Ramaprakasha, \& Rajaram, 2017).

The history of corporate social responsibility (CSR) is perhaps as old as the history of business itself, though the concept was not formally formulated until recently. (Saeid, Zabihollah, \& Zahra, 2015).

Insurance companies' practices are those of sharing losses, of spreading risk lightly over a great number of people so that few unfortunate people who sustain losses do not suffer heavy financial loss as a result of the misfortune. In the view of (Azubike, 2008) the classical scenario of the business accounting for it activities to the stakeholders have more recently witnessed the appearance of interest groups. The interest groups include workers investors, the tax authorities, the host communities and non- governmental organizations. Thus, instead of only having a financial responsibility before its shareholders, it has moved towards a situation where a company has a social responsibility before its stakeholders. (Purnomo \& Widianingsih, 2012), argued that organization social responsibility is represented by a series of obligation to not only safeguard its own interest (economic an effect upon owners, employers, but to be accountable to society's well being (local communities, environment, and national interests). (Osisioma, Nzewi, \& Nwoye, 2015) added that the survival of every business depends on the accomplishment of these objectives. The two broad categories of business objectives expected to be accomplished include economic objectives and social objectives. While economic objectives are the targets to be accomplished in the marketing efforts of an organization, social objectives are associated with the aims of an organization towards satisfying the interest of its shareholders, employees, and the general public. Nevertheless, CSRA is not new to the financial reporting arena, presently in Nigeria, companies in their directors' reports are required to provide in some circumstances information regarding environment of employee involvement in companies' affairs and donation of charitable nature (CAMA, $2004 \mathrm{~S} .342$ part 1 ch 5).

Despite these importance CSRA is still at a slow paced, and the level of social disclosure among Nigeria companies is basically still low and at the embryonic stage which is mainly caused by various bottlenecks of environmental issues as opined by ( Mamman, 2011; Nzewi, Nzewi, Okerekeoti, 2013).

Also, Nigeria insurance companies are still uncertain about the benefits of social reporting and the use of social reporting information benchmark has not been widely practiced.

Against the above backdrop, this study is undertaken with a view to ascertain corporate social responsibility accounting and financial performance of insurance companies in Nigeria 


\section{Objectives of Study}

The main objective of the study is to determine corporate social responsibility accounting on the financial performance of insurance companies in Nigeria. The specific objectives of this study are:

i. To ascertain the relationship between corporate social responsibility accounting and return on capital employed of insurance companies.

ii. To establish the significant relationship between corporate social responsibility accounting and earnings per share of insurance companies

iii. To establish the significant relationship between corporate social responsibility accounting and net profit margin of insurance companies

\section{Research Questions}

To achieve the specific objectives of this study the following research questions were raised:

1. To what extent does corporate social responsibility accounting affects return on capital employed of insurance companies?

2. What is the extent of relationship between corporate social responsibility accounting and earnings per share of insurance companies?

3. To what extent does corporate social responsibility accounting affects net profit margin.

\section{Research Hypotheses}

The following hypotheses were tested in the course of this research study:

Ho1: There is no significant relationship between corporate social responsibility accounting and return on capital employed of insurance companies.

Ho2: There is no significant relationship between corporate social responsibility accounting and earnings per share of insurance companies.

Ho3: There is no significant relationship between corporate social responsibility accounting and net profit margin of insurance companies

\section{REVIEW OF RELATED LITERATURE}

\section{Conceptual review}

Historical Origin of Corporate Social Responsibility (CSR)

The history of CSR can be traced back to 1700 years before Christ in which it was reported that Mesopotamian kings as of then introduced a code for innkeepers guidance on how to go about their jobs. Deviation from complying with the code led to severe penalty especially when the deviations harmed other citizens (Ogunkade, Mafimisebi, 2011).

Researches on corporate social responsibility were dates back to at least 1930s (Berle, 1931; Dodd, 1932). Through the initial stages of CSR research often referred to as social responsibility, the literature was primarily at the institutional level (Uwuigbe, Uwuigbe, \& Ajayi, 2011) with the discourse being around the role of the firm in society ( Bowen, 1953). However, clarity around the role of the firm and especially the conceptualization of CSR did not emerge and it became even less clear over the subsequent decades.

As one of the reasons for the institutions of CSR is to enable mutual beneficial relationship to exist between the business and the hosting environment, one can justify the long existence of the concept by taking into consideration what prominent practicing religions impliedly narrated on business dealings between business owners and members of the society. With industrialization advancement companies now voluntary engaged in discharging CSR. For example according to (Islam, \& Deegan, 2007) Kellog Company has claimed to be discharging CSR since the inception of the company in 1906. Another confirmation of similar incidence is found in (Makori, \& Jagongo, 2013) in which he claimed that corporate paternalists of the late 19th and early 20th centuries used some of their wealth to support philanthropic activities.

Due to the prominent nature of CSR, it is now considered as one of the crucial subject matter of interest in accounting theory and practice since $70^{\text {ee }} \mathrm{s}$. The accounting profession has been involved in the struggle to ensure that social responsibility expenditures are accounted for and adequately disclosed in the annual reports of financial statements (Ojo, 2012).

\section{Corporate Social Responsibility (CSR)}

(Bowen, 1953), called the "Father of Corporate Social Responsibility" by (Carroll, 1979), offered an initial definition of social responsibilities. He said that social responsibilities of a business refer to the obligations of a firm to pursue policies, to make decisions, or to behave according to some lines which bring positive values to society (Carroll, 1979). From then on, corporate social responsibility became a new field to study for both the sake of enterprises and the benefit of the society.

(Davis, 1960) kept studying CSR and he presented "businessmen's decisions and actions taken for reasons at least partially beyond the firm's direct economic or technical interest". Although Davis did not clearly identify what should be included in the scope of CSR, he pointed out that other than pursuing profit, firms should also do well to the society. (Saeid, et. al, 2015). The concept is therefore closely linked to the principle of sustainability, which argues that enterprises should make decisions based not only on financial factors such as profits and dividends, but also based on the immediate and long term social and environmental consequences of their activities (Ojo, 2012).

\section{Social Responsibility Accounting}

The communicating of the extent to which an organization is meeting its stated social ethical goals, This implies that the reports submitted by financial accounting systems reflect a company's performance according to certain perspectives, consider profitability and financial power of the business as a success or failure index, and pay more attention to making profit for such groups as: 


$\begin{aligned} \text { i. } & \text { Active or passive investors } \\ \text { ii. } & \text { Business managers } \\ \text { iii. } & \text { Active or passive creditors } \\ \text { iv. } & \text { Governmental organizations } \\ \text { v. } & \text { Customers } \\ \text { vi. } & \text { Sales persons }\end{aligned}$

\section{Sustainability}

"Sustainability is concerned with the effect which action taken in the present has upon the options available in the future. The starting point for every definition of sustainability comes from the Brundtland Report, which was published in 1987. This is actually a report named Our Common Future which was produced by the World Commission on Environment and Development. It is generally known however as the Brundtland Report after its chair". Sustainability looks into the effect of action taken today and the options available in the future. A situation where we use a particular resource in course of our business, we consider whether the resource will be available for future use. The concern is more on resources that have limited supply. Where a resource is limited in quantity and cannot or will be difficult to be recreated, the question of sustainability comes to play. We must know that whatever resources that are used now will no longer be available to be used in the future. Therefore, for sustainability to be of effect, society must use no more than the resource they can regenerate. Raw materials extracted from the ground are finite in nature. For example; coal, oil and so on. Quantity used of these resources will not be available in the future at some point in time there has to be alternative. Sustainability measures the rate in which resources are consumed by an organization in relation to the rate it can regenerate those resources. In order to sustain unsustainable operations we need to plan for the future need of our operations.

\section{Organizational Performance}

Continuous performance is the objective of any organization because only through performance, are organizations able to grow and progress (Gavrea, Ilies, \& Stegerean, 2011). The concept of corporate performance is fuzzy, as scholars often agree that there is no universal definition of the concept. Scholars often agree that corporate performance is a function of time and organizational context.

(Daft, 1991, cited in Fauzi, Svensson, \& Rahman, 2010) defined corporate performance as the organization's ability to attain its goals by using resources in an efficient and effective manner. (Gavrea et al., 2011) provide a set of definitions to illustrate the concept of organizational performance:

Performance is a set of financial and nonfinancial indicators which offer information on the degree of achievement of objectives and results; Performance is dynamic, requiring judgment and interpretation; Performance may be illustrated by using a causal model that describes how current actions may affect future results; Performance may be understood differently depending on the person involved in the assessment of the organizational performance (e.g. performance can be understood differently from a person within the organization compared to one from outside); To define the concept of performance is necessary to know its elements characteristic to each area of responsibility; and to report an organization's performance level, it is necessary to be able to quantify the results.

\section{Theoretical Framework}

\section{Stakeholders Theory}

Stakeholder theory, states that a company owes a responsibility to a wider group of stakeholders, other than just shareholders. A stakeholder is defined as any person/group which can affect/be affected by the actions of a business. It includes employees, customers, suppliers, creditors and even the wider community and competitors.

Edward Freeman, the original proposer of the stakeholder theory, recognized it as an important element of Corporate Social Responsibility (CSR), a concept which recognizes the responsibilities of corporations in the world today, whether they be economic, legal, ethical or even philanthropic. Nowadays, some of the world's largest corporations claim to have CSR at the centre of their corporate strategy. Whilst there are many genuine cases of companies with a "conscience", many others exploit CSR as a good means to improve their image and reputation but ultimately fail to put their words into action

The stakeholder concept was first used in 1963 internal memorandum at the Stanford Research Institute. They defined stakeholders as "those groups without whose support the organization would cease to exist." The theory was later developed and championed by Freeman in the 1980s. Since then it has gained wide acceptance in business practice and in theorizing related to strategic management, corporate governance, business purpose and corporate social responsibility (Phillips, Freeman, \& Wicks, 2003)

\section{Review of Empirical Studies}

This study carried out by (Okafor, Hassan \& Hassan, 2008) on environmental issues and corporate social responsibility with Nigeria as a case study, data were analyzed using ANOVA, the study reveals that industrial activities have adversely affect the environment creating serious discomfort to the inhabitants especially in the oil producing area of which there is urgent need to seriously address the problem.

(Ramaprakash, et. al, 2017) examines an analysis of corporate social responsibility initiative of selected manufacturing companies in Karanataka. India's top 500 companies' reports were selected for this study. A total of 14 manufacturing companies from Karanataka figured in Dun and BradStreet's report were use for the study. Data were analyzed using Predictive Analysis Software Statistics 18 and Cochran's Q test. Findings show that there is significant difference in the orientation of corporate social responsibility initiative of the selected manufacturing companies in Karanataka. The study concluded that the new companies 
Act 2013 has redefined the way companies operate in India as against the previous practices where companies were focusing on increasing the value of shareholders.

(Olowokudejo, \& Aduloju, 2011) making use of survey data analyzed with $\mathrm{t}$ test discovered that involvement in corporate social responsibility have positive relationship with organizational effectiveness and therefore, conclude that being socially responsible can help companies succeed, increase their profitability and overall performance.

(Ngwakwe, 2009) investigated the relationship between firms ${ }^{\text {ee }}$ social responsibility practices and their performance in Nigeria. The study focuses on the manufacturing industry and concluded that a positive relationship exists between the social responsibility practice of firms and their performance.

(Akindele, 2011) carried out a study on corporate social responsibility as an organizational tool for survival in Nigeria by examining four major banks in Osogbo, Osun State in order to identify the extent of participation of the banking industry in CSR using primary source of data collection procedure through the administration of questionnaire. Frequency distribution was used to analyze the data and the findings of the study revealed that about $90 \%$ of the participants indicated that the extent of participation of the banks in social responsibility activities is high.

(Uadiale, et al., 2011) examined the impact of CSR activities on financial performance in developing economies. The study considered employee relations (ER), company performance (CP) and environmental management system (EMS) to be the independent variables, while the individual dependent variables were measured with Return on Equity (ROE) and Return on Assets (ROA) in Nigerian companies. The study used a sample of forty audited financial statements of quoted companies in Nigeria. The results showed that CSR has a positive and significant relationship with the financial performance measures.

(Bolanle, Olanrewaju \& Muyideen, 2012) examined corporate social responsibility and profitability of Nigerian banks based on causal relationship by using First Bank of Nigeria Plc as the case study for the period of ten years (2001-2010). CSR was considered as the independent variable while PAT was the dependent variable. The data collected for the study were analyzed by using correlation and regression analysis. The outcome of the research showed a significant positive impact of CSR on PAT. The study recommended the need for banks to demonstrate high level of commitment to corporate social responsibility in order to enhance their profitability in the long run.

(Brine, \& Hackett, 2006) observed the relationship between financial performance and corporate social responsibility across the total population of the top 300 Australian listed companies for the year 2005 financial year out of which 277 companies were drafted into the sample after dropping companies that did not meet the requirement. The study considered corporate social responsibility as the independent variable while financial performance as the dependent variable and data were analyzed by regression. The measurement was based on whether companies made separate sustainability disclosure beyond what is required of them by the regulatory frame work and the measurement of CSR was a dummy variable. The measurement used was ROA, ROE and ROS. The preliminary results revealed no statistical significant relationship exists between the adoption of corporate social responsibility and a firm's financial performance.

(Setiawan, \& Janet, 2012) examined Corporate Social Responsibility, Financial Performance, and Market Performance of consumer goods companies listed on the Indonesian Stock Exchange during the period 2007-2010. The analysis is completed by regression from interviewing consumers, investors, and stock analysts from financial institution in Surabaya, Indonesia. The results of the study show that corporate social responsibility leads to increase in financial performance, but have no significant effect to market performance. Corporate social responsibility will build consumers ${ }^{\text {ee }}$ trust about the products and will encourage them to be loyal consumers. However, investor and stock analyst state that corporate social responsibility is a long term social investment that does not have a significant effect to the investment decision. In addition, most of the companies in the Indonesian consumer goods industry have a good financial performance, so that the stock prices remain constant

(Wissink, 2012) examined the relationship between corporate social performance and corporate financial performance. On the whole, the combined results suggested that the relationship between corporate social responsibility and corporate financial performance is at least neutral and perhaps slightly positive. However, the different approaches make it difficult to come to a final answer. But the result was put to the test once more, but only after trying to come to a more universal conceptualization and operationalisation of the variables, based on the inclusion of Dow Jones Sustainability Index and Corporate financial performance was operationalised by means of three different accounting variables: ROA, ROE and ROS. The world's 2,500 largest companies were assessed on general and industry specific sustainability criteria by means of self-report questionnaires, media- and stakeholder analysis, and data from secondary sources (company websites, annual reports, etc.). Instrumental stakeholder theory delineates a positive relation from CSP to CFP based on relations with stakeholders; CSR has a positive impact on a corporation's relationship with stakeholders, these improved relationships ultimately result in financial performance. Two hypotheses were tested by means of multivariate statistical tests. Based on the results of these tests, the following conclusions were drawn. Size and institutional context are determinants of corporate social performance (CSP); larger firms have a greater chance of being included in the DJSI, as do firms originating from Europe compared to those from North America. ROA and ROS are positively related to subsequent social perform 
slack resources theory. CSP is positively related to subsequent financial performance, providing evidence of the instrumental stakeholder theory. Taken together, the results provide evidence of a virtuous cycle of CSR. Better CFP results in better CSP and, in turn, better CSP results in better financial performance.

(Osisioma, et.al., 2015) in their study examined the relationship between corporate social responsibility and performance of selected firms in Nigeria. The specific objective of the study was to determine if there was any significant relationship between social responsibility cost and corporate profitability in the selected firms. The study was based on the stakeholder theory of social responsibility which emphasized the need for a corporate organization to satisfy the requirements of various interest groups. Exploratory research design was employed with the use of time series data. The study utilized time series data that involve social responsibility expenditure and profit after tax of the selected firms which covered a period of five years (2007 - 2011). Product moment correlation was used to test the hypothesis and to determine whether there is any significant relationship between social responsibility cost and corporate profitability in the selected firms. Findings revealed a significant relationship between social responsibility cost and corporate profitability. Therefore, the study concluded that social responsibility was vital to organizational performance. It is recommended that firms in Nigeria should endeavour to increase their commitment to social responsibility by setting aside substantial amount of their income to social responsibility programmes.

In a much related study, (Ijeoma, \& Oghoghomeh, 2014) determine the contribution of corporate social responsibility on organizational performance. The purpose of this study was to determine the contribution of corporate social responsibility on company's profit after tax and to ascertain if there exists significant contribution of corporate social responsibility on company's profit after tax. The source of data for this study was secondary data obtained from Central Bank of Nigeria Statistical Bulletin 2010 and annual reports 2008-2012 of three selected public limited companies operating in Nigeria. The statistical tool employed was the regression analysis and the line graph analysis. From the result of the analysis it was found that corporate social responsibility was able to explain and contribute significantly to company's performance more in OANDO Group Nig. Plc since it was able to explain about $96.1 \%$ of the behavior of profit after tax in OANDO Group Nig. Plc, $21.4 \%$ in Guiness Nig. Plc and 9.5\% in Total Nig. Plc. This result implies that OANDO Group Nig. Plc was observed to spend more in terms of corporate social responsibility amongst the observed company's and in turn corporate social responsibility contributing to its performance. Also, it was found that Guniess Nig. Plc recorded the largest profit after tax over the observed period followed by OANDO Group Nig. Plc. It can be generalized that sustainability reports does have an association with company performance. Social performance disclosure has an association with company's performance as was found by the result of OANDO Group Nig. Plc. For companies, improving sustainability performance is important and it is equally important as improving company's financial performance. Sustainability means the development that meets the needs of the present without compromising the ability of future generations to meet their own needs. It means that, in running the business, a company need to concern to the needs of future generations. Though reporting on its environmental performance may expose a company to criticisms and also have minimal effect in the short run. It is advisable that the company continues to disclose its environmental performance because in the long run it would help in achieving sustainability.

(Kamatra \& Kartikaningdya, 2015). This study was conducted to examine the effect of CSR on financial performance as measured by profitability ratios consisting of return on assets (ROA), return on equity (ROE), net profit margin (NPM) and earnings per share (EPS). The population used in this study was the company mining and basic industry chemicals listed in Indonesia stock exchange during the period 2009-2012, while the sample used in this study using purposive sampling technique. Sample as many as 24 companies in Indonesia. This study used a quantitative approach and the method of multiple linear regression analysis of the data, with the first through the classical assumption. The results of this study indicate that simultaneous CSR and control variables consisting of leverage (DER) and size effect on ROA, ROE, NPM and EPS. CSR only has partially significant effect on ROA and NPM and no significant effect on ROE and EPS.

\section{METHODOLOGY}

The research design adopted by the study was expo factor research design. The population of the study consists of all the 40 insurance companies quoted by Nigeria Stock Exchange as at December 2016 are shown in appendix 1. The sample for the study was by applying statistically the Taro Yamane formula in determining the sample and the 25 insurance companies were selected by random sampling technique base on their size, data collection used by the researcher was the secondary source of data. This includes the annual reports and accounts

list of selected insurance companies

\begin{tabular}{|c|c|c|c|}
\hline S/n & Name of Company & $\mathbf{S} / \mathbf{n}$ & Name of Company \\
\hline 1 & $\begin{array}{c}\text { Allco Insurance } \\
\text { American Inter. Plc }\end{array}$ & 14 & NEM Insurance plc \\
\hline 2 & $\begin{array}{c}\text { Consolidated Hallmark } \\
\text { Insurance Plc }\end{array}$ & 15 & $\begin{array}{c}\text { NPF Micro Finance } \\
\text { PLC }\end{array}$ \\
\hline 3 & $\begin{array}{c}\text { Continental } \\
\text { Reinsurance plc }\end{array}$ & 16 & Niger Insurance Plc \\
\hline 4 & $\begin{array}{c}\text { Cornerstone Insurance } \\
\text { Plc }\end{array}$ & 17 & Prestige Insurance Plc \\
\hline 5 & $\begin{array}{c}\text { Custodian \& Allied } \\
\text { Insurance plc }\end{array}$ & 18 & $\begin{array}{c}\text { Regency Alliance } \\
\text { Insurance Plc }\end{array}$ \\
\hline
\end{tabular}


International Journal of Academic Accounting, Finance \& Management Research (IJAAFMR)

ISSN: 2000-008X

Vol. 3 Issue 5, May - 2019, Pages: 16-25

\begin{tabular}{|c|c|c|c|}
\hline 6 & Equity Assurance Plc & 19 & $\begin{array}{l}\text { Royal Exchange } \\
\text { Insurance Plc }\end{array}$ \\
\hline 7. & Guinea Insurance Plc & 20 & $\begin{array}{l}\text { Sovereign Trust } \\
\text { Insurance Plc }\end{array}$ \\
\hline 8 & $\begin{array}{l}\text { International Energy } \\
\text { Insurance Plc }\end{array}$ & 21 & Staco Insurance plc \\
\hline 9 & Lasaco Assurance Plc & 22 & $\begin{array}{l}\text { Standard Alliance } \\
\text { Insurance Plc }\end{array}$ \\
\hline 10. & $\begin{array}{l}\text { Law Union \& Rock } \\
\text { Insurance Plc }\end{array}$ & 23 & Unic Insurance Plc \\
\hline 11 & Linkage Assurance plc & 24 & $\begin{array}{l}\text { Unity Kapital } \\
\text { Assurance Plc }\end{array}$ \\
\hline 12 & Mansard Insurance Plc & 25 & Wapic Insurance Plc \\
\hline 13 & $\begin{array}{c}\text { Mutual Benefits } \\
\text { Assurance Plc }\end{array}$ & & \\
\hline
\end{tabular}

Source: Nigeria Stock Exchange 2016

Method of Data Analysis

The study employs parametric statistical techniques using multiple regression analysis techniques for testing hypotheses

\section{Model Specification}

$\mathrm{CSRC}=\mathrm{f}(\mathrm{ROCE}, \mathrm{EPS}, \mathrm{NPM}$,

Where:

CSRC $=\quad$ Corporate Social Responsibility Cost of

Companies

ROCE $=\quad$ Return on Capital Employed

EPS = Earnings per Share

NPM $=$ Net Profit Margin

The econometric form of the model is as follows:

$\mathrm{CRSC}=\mathrm{b}_{0}+\mathrm{b}_{1} \mathrm{ROCE}+\mathrm{b}_{2} \mathrm{EPS}+\mathrm{b}_{3} \mathrm{NPM}_{+} \mu_{\mathrm{t}}$

\section{DATA PRESENTATION AND ANALYSIS}

Descriptive Statistics of Variables for Various insurance companies

\begin{tabular}{r|r|r|r|r|}
\hline Year & AMT ON CRS & \multicolumn{1}{|c|}{ ROCE } & \multicolumn{1}{c|}{ EPS } & \multicolumn{1}{c|}{ NPM } \\
\hline 2007 & 839861945.00 & 177.69 & 58.19 & 309.42 \\
2008 & 1727296658.00 & 248.71 & 54.81 & 387.19 \\
2009 & 2024522701.00 & 140.20 & 93.35 & 13.67 \\
2010 & 4078581999.33 & -43.63 & -60.77 & -36.30 \\
2011 & 2555924248.56 & 223.38 & 69.62 & 277.28 \\
2012 & 3130248840.00 & -4.94 & -115.62 & -186.82 \\
2013 & 2088971478.00 & 199.61 & 217.17 & 253.85 \\
2014 & 3761902539.30 & 233.30 & 69.05 & 253.96 \\
2015 & 3456242987.00 & 253.94 & 66.52 & 290.94 \\
2016 & 2429445454.00 & 154.91 & 51.55 & 201.55
\end{tabular}

Source: Annual Reports and Accounts (2007-2016)

In analyzing the data presented in the above table, the ordinary least square regression method was used with the EView (7.0) version. The result of the data analysis is presented below.

Analysis of Result

Table 4.2.2: Result of Normality Test

\begin{tabular}{|c|c|c|c|c|}
\hline & AMT_ON_CR & & & \\
& S & EPS & NPM & ROCE \\
\hline Mean & $1.86 \mathrm{E}+08$ & 3.599071 & 12.60529 & 11.30836 \\
\hline Median & 81272050 & 0.985000 & 17.28500 & 13.34000 \\
\hline Maximum & $1.96 \mathrm{E}+09$ & 159.4000 & 65.60000 & 83.33000 \\
\hline Minimum & 0.000000 & -157.9800 & -316.5500 & -74.01000 \\
\hline Std. Dev. & $2.69 \mathrm{E}+08$ & 22.58879 & 40.71497 & 17.19228 \\
\hline Skewness & 2.945884 & -0.229809 & -5.895550 & -1.174540 \\
\hline Kurtosis & 16.10985 & 36.85687 & 45.06812 & 11.33634 \\
\hline & & & & \\
\hline Jarque-Bera & 1205.056 & 6687.909 & 11134.41 & 437.5739 \\
\hline Probability & 0.000000 & 0.000000 & 0.000000 & 0.000000 \\
\hline & & & & \\
\hline Sum & $2.61 \mathrm{E}+10$ & 503.8700 & 1764.740 & 1583.170 \\
\hline Sum Sq. Dev. & $1.01 \mathrm{E}+19$ & 70925.24 & 230421.5 & 41084.85 \\
\hline Observations & 140 & 140 & 140 & 140 \\
\hline
\end{tabular}

Source: Eviews 7.0

respectively. The mean value for NPM stood at 12.61 with a

Table 4.2.2 presents the result for the normality test conducted to ascertain the normality distribution of the error term of the variables under consideration. As observed AMT on CSR have a mean value of $1.86 \times 10^{8}$ and a standard deviation of $2.69 \times 10^{8}$. The maximum and minimum values stood at $1.96 \times 10^{9}$ and 0.00 respectively. EPS is observed to have a mean of 3.60 and a standard deviation of 22.59. The maximum and minimum values were 159.40 and -157.98 standard deviation of 40.71. The maximum and minimum value for NPM is 65.6 and -316.55 respectively. ROCE was observed to have a mean value of 11.31 and a standard deviation of 17.19. The maximum and minimum ROCE are 83.33 and -74.01 respectively. An evaluation of the JacqueBera statistic for the variables indicates that all the variables appear not normally distributed $(\mathrm{p}<0.0001)$, because the probability of Jarque-Bera is less than 0.05 in the model 
International Journal of Academic Accounting, Finance \& Management Research (IJAAFMR) ISSN: 2000-008X

Vol. 3 Issue 5, May - 2019, Pages: 16-25

Table 4.2.4: Result of Ordinary Least Square Regression

\begin{tabular}{|l|c|c|c|c|}
\hline Variable & Coefficient & $\begin{array}{c}\text { Std. } \\
\text { Error }\end{array}$ & t-Statistic & Prob. \\
\hline C & $1.64 \mathrm{E}+08$ & 27340382 & 5.982498 & 0.0000 \\
\hline EPS & -892000.0 & 1037122. & -0.860073 & 0.3913 \\
\hline NPM & 220150.2 & 702611.6 & 0.313331 & 0.7545 \\
\hline ROCE & 2056010. & 1690153. & 1.216464 & 0.2259 \\
\hline
\end{tabular}

Source: Eviews 7.0 Parametric test results for insurance companies

From table 4.2.3 above, the ordinary least square regression result reveals a negative relationship of EPS (-0.86), positive relationship NPM (0.31) and ROCE (1.21) of the variables examined. Also, a negative correlation exists between EPS and AMT ON CSR (-892000). NPM has a positive relationship with AMT ON CSR (220150.2); while ROCE has a positive relationship with AMT ON CSR (2056010). This result is summarized below:

$A M T \_O N_{-} C S R=1.64 E+8-892000 E P S+220150.2 N P M+2056010 R O C E+U_{t}$

$$
(5.98) \quad(-0.86) \quad(0.31) \quad(1.22)
$$

Discussion of Findings

The study aimed at looking at the corporate social responsibility accounting and financial performance of insurance companies in Nigeria. In an effort to achieve this three independent variables were used against one dependent variable. The independent variables used by the model to represent financial performance are Return on capital employed (ROCE) Earning per share (EPS) and Net profit margin (NPM). The dependent variable used for corporate social responsibility accounting (CSRA) was amount on social responsibility cost (ASRC) incurred by insurance companies for a period of ten years. The study found that two of the independent variables have a strong positive relationship between AMT ON CRS and ROCE, and NPM with the ordinary least square regression result that reveals a positive relationship ROCE (1.21) and NPM (0.31) of the variables examined. And a positive correlation of AMT ON CSR (2056010) and NPM (220150.2). The result of the study lends credence to the findings (Olowokudejo \& Aduloju, 2011) found that involvement in corporate social responsibility have positive relationship with organizational effectiveness which will increase profitability and overall performance.

(Ngwakwe, 2009; Gunu, 2008; Uadiale \& Fagbemi, 2011; Bolanle et al, 2012; Servaes \& Tamayo, 2012; Yang, Lin \& Chang, 2010; Osisioma, Nzewi \& Nwoye, 2015). these study shows that there is a positive relationship between company financial performance measures and corporate social responsibility performances.

The study found that Hypothesis 2, have no significant relationship between corporate social responsibility accounting and earnings per share of insurance companies. This is reveals by the ordinary least square regression result of EPS (-0.86), and that a negative correlation exists between EPS and AMT ON CSR (-892000).
The study of Adebayo et al. (2012) supported this result that the performance of corporate social responsibility has no correlation with return on equity. While (Afonso, Fernandes $\&$ Monte, 2012) found out those companies belonging to group of Medium CSR were worst only in ROE and Low CSR companies. The total negative correlation between CSR Index and ROE, in the Low CSR companies, that had the better result in ROE and the worst in ROA, it may also indicate that a focus in results to shareholders, neglecting social performance, may have a negative impact in other dimensions.

\section{FindingS AND RECOMMENDATION}

\section{Summary of Findings}

The study reveals the following findings;

1. The ordinary least square regression result of AMT_ON_CSR (5.98) and ROCE (1.22) for hypothesis 1 , have a positive and significant relationship between corporate social responsibility accounting and return on capital employed of insurance companies.

2. That the ordinary least square regression result of AMT_ON_CSR (5.98) and EPS (-0.86) for hypothesis 2 , have negative and no significant relationship between corporate social responsibility accounting and earnings per share of insurance companies

3. The ordinary least square regression result of AMT_ON_CSR (5.98) and NPM (0.31) for hypothesis 3, have a positive and significant relationship between corporate social responsibility accounting and net profit margin of insurance companies in Nigeria

\section{Recommendations}

Based on findings, the study recommends the following to the various stakeholders.

1. Management of insurance companies should ensure that social responsibility is inbuilt into their policy statements and back up with effective budget giving the fact that CRS leads to profit realization. Furthermore, management should create a unit or department within their firms that will be responsible for their social responsibility programmes which should ensure that their social responsibility policies are adequately implemented, and ensure that Nigerian companies comply with government laws regarding business regulation in the country.

2. Shareholders at the annual general meeting should encourage the management of their companies to have well structured corporate social responsibility programme in view of it benefits.

3. Employees should be more effective and efficient in discharging their functions. By being effective and efficient the companies can be able to render services at low cost which by extension means part 
of the money saved could be used in attaining responsibility issues.

\section{REFERENCES}

1. Afonso, S. C., Fernandes, P. O., \& Monte, A. P. (2012) CSR of top Portuguese companies: relation between social performance and economic performance. World academy of science, engineering and technology (66).

2. Akindele, R.I. (2011). Corporate social responsibility: An organizational tool for survival in Nigeria. www.readperiodicals.com

3. Berle, A. A.( 1931). Corporate powers as powers in trust. Harvard Law Review, 44: 1049- 74. http://dx.doi.org/10.2307/1331341

4. Brine, M; R. B., \& Hackett, G. (2006): "Corporate social responsibility and financial performance in the Australian context ". Corporations and financial services Division, the Australian treasury.

5. Bolanle, A.B. Olanrewaju, A. S. \& Muyideen, A. A. (2012). Corporate social responsibility and profitability of Nigeria banks- causal relationship. Research journal of finance and accounting ISSN 2222-1697 3, (1).

6. Bowen, H.R. (1953). Social responsibilities of the businessman, Harper \& Row, New York, NY.

7. Carroll, A.B. (1979), "A Three-Dimensional Conceptual Model of Corporate Performance" Academy of Management Review, 1979, Vol. 4, No. 4, p. 500

8. Companies And Allied Matters Act ,Cap C20, Lfn 2004.

9. Dahlsrud, A. (2006). How corporate social responsibility is defined: an analysis of 37 definitions. Corporate Social Responsibility and Environmental Management, September. Available at: http://www.csrnorway.no/papers/2007_dahlsrud_CSR.pdf

10. Davis, K. (1960). Can business afford to ignore social responsibilities? California management Review, 2, pp. 70-76.

11. Dodd, E. M. (1932). For whom are corporate managers trustees. Harvard law Review, 45: 1145-63. http://dx.doi.org/10.2307/1331697

12. Fauzi, H., Svensson, G., \& Rahman, A. (2010). Triple Bottom Line as "Sustainable Corporate Performance" A Proposition for the Future. Sustainability, 2(5), 13451360.

13. Fatula, O. (2007). "The imperative of Recapitalisation and Consolidation in the Nigeria Insurance Industry" I (I\&II), Ikeja Bar Review, p. 128.

14. Gavrea, C., Ilies, L., \& Stegerean, R. (2011). Determinants of organizational performance: The case of Romania. Management \& marketing, 6(2), 285-300.
15. Ijeoma, N. B., \& Oghoghomeh, T. (2014). Determining the contribution of corporate social responsibility on organizational performance. International journal of economics, finance and management sciences. 2, (1), pp. 84-91

16. Islam, M. A. \& Deegan, C. (2007). Motivation for an organization within a developing country to report social responsibility information. Accounting Auditing \& Accountability Journal, 21, pp 850-874.

17. Kamatra, N. \& Kartikaningdya, E.,(2015). Effect Corporate Social Responsibility on Financial Performance. International Journal of Economics and Financial Issues | Vol 5 • Special Issue. P 157-165.

18. Makori, D. M. \& Jagongo, A. (2013). Environmental accounting and firm profitability: An empirical analysis of selected firms listed in Bombay stock exchange, India. International journal of humanities and social science 3(18) pp 248- 255.

19. Mamman, S. (2011). Environmental challenges of accounting for corporate social responsibility by firms in Nigeria. Journal accounting publication of the department of accounting, Bayero University Kano, edited by Kabiru Isah Dandago and Bashir Tijjani, Adamu Joji publishers, Kano Nigeria

20. Ngwakwe, C. C. (2009). Environmental responsibility and firm performance: Evidence from Nigeria. International journal of humanities and social sciences, 3, 2-22

21. Nzewi, U.C., Nzewi, H. \& Okerekeoti, C, (2013). Appraisal of corporate social responsibility accounting in Non-bank quoted companies in Nigeria. Quarterly Journal of Association of National Accountants of Nigeria ISSN 0189-0662 Vol.25 No1 January

22. Ogunkade, A., \& Mafimisebi, S. (2011). Contributions of corporate social responsibility to agriculture

23. and rural development in Nigeria. Journal of sustainable development in Africa, 13 (3).

24. Ohaka, J. \& Ogaluzor, O. (2018) Corporate Social Responsibility Accounting and the Effect of

25. Donations on Profitability of Oil and Gas Companies in Nigeria. International Journal of Academic Research in Accounting, Finance and Management Science Vol. 8, No. 3. July 2018,pp 265-276

26. Ojo, O. (2012). Appraisal of the practice of social responsibility by business organization in Nigeria. Retrieved from http:// www.google.com.ng

27. Okafor, E. Hassan A.R. \& Hassan, A.D. (2008). Environmental issues and corporate social responsibility: The Nigerian experience 
28. Oleg, D. \& Nino, K. (2017). Corporate Governance, Social Responsibility and Financial

29. Performance of European Insurers. Acta Universitatis Agriculturae Et Silviculturae Mendelianae Brunensis.

30. Olowokudejo, F. \& Aduloju, S.A. (2011). Corporate social responsibility and organizational effectiveness of insurance companies in Nigeria. Retrieved from http:// www.emeraldinsight.com/1526-5943.htm

31. Osisioma, H., Nzewi H., \& Nwoye P. (2015). Corporate social responsibility and performance of selected firms in Nigeria. International journal of research in business management (IMPACT: IJRBM) ISSN(E): 2321-886X; ISSN(P): 2347-4572 Vol. 3 pp 57-68

32. Phillips, R., Freeman, R. E., \& Wicks, A. C. (2003). What stakeholder theory is not? Business Ethics Quarterly 13(4). Pp479-502.

33. Purnomo, P. K. \& Widianingsih, L. P. (2012). The influence of environmental performance on financial performance with corporate social responsibility (CSR) disclosure as a moderating variable: Evidence from listed companies in Indonesia Rev Integr Bus. Econ. Res. Vol 1(1) 57 Copyright 2012 Society of interdisciplinary business research (www.sibresearch.org)

34. Ramaprakash, N., \& Rajaram, Y. (2017). An Analysis of Corporate Social Responsibility Initiative of Selected Manufacturing Companies in Karanataka. IOSR Journal of Business and Management e-ISSN:2278-487X, PISSN:2319-7668.P23-28

35. Saeid, H., Zabihollah, R. \& Zahra, A. ,(2015). Corporate social responsibility and its relevance to accounting. Journal of sustainable development; Vol. 8, No. 9; pp 178-189. Published by Canadian center of science and education.

36. Setiawan, E. \& Janet, T. J. (2012). Corporate social responsibility, financial performance, and market performance: Evidence from Indonesian consumer goods industry

37. Uadiale, O. M. \& Fagbemi, T. O.( 2011). Corporate social responsibility and financial performance in developing economies: The Nigerian experience. The 2011 New Orleans international academic conference.UK evidence from disaggregate measures, financial management 35, 97-116.

38. Uwuigbe, U. \& Egbide, B. (2012). Corporate social responsibility disclosures in Nigeria: A study of listed financial and non-financial firms. www.Ccsenet.Org/Jms Journal of management and sustainability Vol. 2, No. 1; March 2012160 ISSN 1925-4725 E-ISSN 1925-4733

39. Uwuigbe, U., Uwuigbe, O., \& Ajayi, A. .O. (2011). Corporate social responsibility disclosures by environmentally visible corporations: A study of selected firms in Nigeria. European journal of business and management, 3, (9),pp 9-17

40. Vitezić, N. (2011). Correlation between social responsibility and efficient performance in Croatian enterprises Zb. rad. Ekon. fak.Rij. - 2011 - vol. 29 - sv. 2 - 423-442 423

41. Wissink, R. (2012). Testing the relation between corporate social performance and corporate financial performance. Master thesis R.B.A Wissink University of twente business administration

42. Yang, F. Lin, C. \& Chang, Y. (2010). The linkage between corporate social performance and corporate financial performance. African journal of business management Vol. 4(4), Pp 406-413.

\section{APPENDIX 1}

Insurance Companies Quoted on Nigeria Stock Exchange (NSE) as at December 2016

\section{A. Insurance}

1. Africean Alliance Insurance Plc

2. Allico

3. Continental Reinsurance Plc

4. Cornerstone Insurance

5. Costodian \& Allied Insurance Plc

6. Equity Assurance Plc

7. Great Nigeria Insurance Plc

8. Goldlink Insurance Plc

9. Guinea Insurance Plc

10. Consolidated Hallmark Insurance Plc

11. Investment \& Allied Assurance Plc

12. International Energy Insurance Plc

13. Lasaco Assurance Plc

14. Law Union \& Rock Insurance Plc

15. Linkage Assurance Plc

16. Mansard Insurance Plc

17. Mutual Benefits Assurance Plc

18. N.E.M Insurance Co. Nig Plc

19. Niger Insurance Co. Plc

20. Oasis Insurance Plc

21. Prestige Assurance Co Plc

22. Regency Alliance Insurance Plc

23. Sovereign Trust Insurance Plc

24. Staco Insurance Plc

25. Standard Alliance Insurance Plc

26. Unic Insurance Plc

27. Unity Kapital Assurance Plc

28. Universal insurance company Plc

29. Wapic

30. Fortis Microfinance Bank Plc

31. NPE

32. Abbey Building society Plc

33. Aso Saving and loans Plc

34. Resort saving and loans Plc 
International Journal of Academic Accounting, Finance \& Management Research (IJAAFMR) ISSN: 2000-008X

Vol. 3 Issue 5, May - 2019, Pages: 16-25

35. Union Homes savings and loans Plc

36. Africa prudential registrants Plc

37. Deap capital management Plc

38. Nigeria energy sector fund Plc

39. Royal exchange Plc

40. Sim capital Alliance value Plc

Source: Nigeria Stock Exchange (NSE) as at December 2016 